Al-Madrasah: Jurnal Ilmiah Pendidikan Madrasah Ibtidaiyah

Vol. 6, No. 1, 2022

DOI 10.35931/am.v6i1.832

P-ISSN: 2620-5807; E-ISSN: 2620-7184

\title{
MODEL KELAS ANWAHA \\ MANAJEMEN PEMBELAJARAN TATAP MUKA MASA COVID 19
}

\author{
Syahrani \\ Dosen STAI Rakha Amuntai \\ syahranias481@gmail.com
}

\begin{abstract}
Abstrak
Covid 19 berpengaruh terhadap percepatan adaptasi digital dunia pendidikan dengan gencarnya pembelajaran daring, namun berdampak negatif setelah berlangsung selama 1 tahun lebih dengan terlihat lemahnya kognitif anak yang tidak sesuai dengan kelas yang didudukinya. Penelitian ini bertujuan sebagai tindakan refleksi dari hasil penerimaan santri baru dan santri pindahan pada semua jenjang sekolah yang diselenggarakan Pondok Pesantren Anwarul Hasaniyyah (Anwaha). Metode Research and Development digunakan untuk merancang model kelas anwaha dalam tindakan manajemen pembelajaran tata muka masa covid 19. Hasil penelitian menunjukkan bahwa model ini sangat berpengaruh dalam peningkatan kognitif siswa dengan opersionalnya berupa penggabungan kelas 1, 2 dan 3, gabungan kelas 4 dan 5, kelas 6 tidak digabung, namun selama 3 bulan membahas materi kelas 4 dan 5, selanjutnya penggabungan kelas 7 dan 8, sedangkan kelas 9 tidak digabung, namun diisi dengan pembahasan materi kelas 7 dan 8 bagi siswa kelas 9, penggabungan kelas 10 dan 11, pembahasan materi kelas 10 dan 11 bagi kelas 12 yang berlangsung selama 3 bulan yakni bulan juli, agustus dan september dan kembali ke kelas normal pada bulan oktober guna persiapan ujian semester ganjil dan dalam manajemen pembelajaran tatap muka dengan model kelas anwaha minimal harus terpenuhi 5 dari 6 syarat dan tidak boleh melakukan kelas gabungan untuk jenjang akhir pendidikan serta penerapan model kelas anwaha maksimal 3 bulan.
\end{abstract}

Kata Kunci: Model Kelas, Manajemen Pembelajaran, Covid 19, Anwaha

\section{PENDAHULUAN}

Penyelenggaraan pendidikan semua jenjang dipaksa untuk beradaptasi dengan pandemi dan dipaksa untuk menjalankan pendidikan beda dari biasanya yang awalnya terbiasa belajar berhadapan langsung antara santri dan ustadz menjadi tatap muka hanya lewat daring karena terjadi wabah covid mulai tahun 2019 dan mulai menyebar di tahun 2020. Proses pembelajaran dengan melakukan kegiatan berupa pertemuan online tanpa adanya interaksi langsung antara guru dan santri dalam pemberian materi pelajaran dan hal ini dianggap wajar karena memang era digital 4.0 memasuki era 5.0. ${ }^{1}$

${ }^{1}$ Rahmatullah, A. S., Mulyasa, E., Syahrani, S., Pongpalilu, F., \& Putri, R. E. (2022). Digital era 4.0: The contribution to education and student psychology. Linguistics and Culture Review, 6, 89-107.

Al-Madrasah: Jurnal Ilmiah Pendidikan Madrasah Ibtidaiyah Vol. 6, No. 1, Januari-Maret 2022 
Model pembelajaran seperti ini berlaku dan diberikan mulai dari anak-anak usia dini yang sekolah di PAUD atau TK sampai pada mahasiswa yang kuliah di kampus.

Proses pembelajaran akan terlaksana ketika terjadinya proses interaksi melalui kegiatan belajar dan kegiatan mengajar yang dilakukan oleh ustadz dan santri. Kegiatan pembelajaran yang diawali seperti inilah yang berpeluang meningkatkan keberhasilan siswa dalam mencapai tujuan pendidikan mereka ditentukan. Selain dari itu, sebenarnya saat adanya proses pembelajaran yang terjadi tentu dapat terlihat dari adanya perubahanperubahan yang membuat siswa menjadi lebih tahu terhadap sesuatu yang baru serta akan punya keterampilan baru atau semakin menguasai banyak ilmu pengetahuan dibanding kondisi sebelumnya. Namun pembelajaran seperti ini akan terganggu dengan dilanda pandemi lebih dari setahun lamanya yang secara tiba-tiba muncul menjadi krisis kesehatan sebagaimana yang dialami oleh penduduk seluruh negara (dunia). Covid-19 yang melanda negeri ini tidak hanya memberi pengaruh pada lembaga pendidikan semua tingkatan atau jenjang perguruan tinggi hingga sekolah menengah saja, tetapi sudah dimulai dari pendidikan anak usia dini hingga sekolah dasar. Sehingga santri (siswa) maupun mahasantri (mahasiswa) memiliki kewajiban untuk menyiapkan diri dan memiliki kemampuan untuk belajar secara mandiri di rumah untuk melindungi diri dan orang-orang terdekat dari penyebaran virus corona. Namun fakta sebenarnya, ada sebagian siswa tidak mampu beradaptasi lebih cepat melalu pembelajaran online.

Pembelajaran dengan cara online ini hanya membuat sebagian santri kurang paham terhadap materi yang diberikan kepada mereka sendiri sebab kegiatan pembelajaran terasa kurang maksimal. Akibatnya, kemampuan santri dalam memahami materi pelajaran yang disampaikan ustadz akan semakin menurun, meskipun sebenarnya dengan terjadinya pandemi ini akan menampilkan contoh sistem pendidikan yang akan dilaksanakan pada masa yang akan datang yang tentunya tidak lepas dari adanyan bantuan teknologi pendidikan. Tapi bagaimanapun canggihnya penggunaan digitalisasi dalam pembelajaran, tentunya guru, dosen, seluruh tenaga pendidik dan kependidikan kegiatan interaksi belajar yang terjadi antara guru dan siswa yang menjadi penyebab terjadinya proses pembelajaran tetap tidak akan mampu menggantikannya. Kegiatan pembelajaran tidak sekedar untuk mendapatkan ilmu dan memahami ilmu pengetahuan saja, namun bertujuan juga untuk memberikan pencapaian nilai baik dalam pembentukan 
karakter sehingga siswa makin berakhlak ataupun pemahaman materi sehingga makin cerdas, adanya pembentukan kerja sama untuk mencapai kondisi terbaik.

Digitaliasi saat pandemi ini memberikan tantangan kepada semua siswa dalam penggunaan dan pemanfaatan teknologi dalam kegiatan belajar yang mereka gunakan untuk meningkatkan perkembangan dunia pendidikan. Namun pada waktu yang hampir bersamaan, adanya berbagai kendala memberikan kesempatan kepada semua santri dan ustadz serta orang tua maupun wali santri (siswa) yang sudah mendampingi anak-anaknya dalam penggunaan teknologi yang berfungsi membantu ssiswa menjadi lebih kompeten dalam menjadi pendidikan masa pandemi yang adaptif terhadap teknologi digitalisasi. ${ }^{2}$

Ada banyak aplikasi untuk media pembelajaran yang sudah tersedia di google play dan play store, baik yang disediakan oleh pemerintah maupun yang disediakan oleh pihak swasta. Pemerintah telah mengeluarkan surat edaran melalui Menteri Pendidikan dan Kebudayaan nomor 9 tahun anggaran 2018 tentang bagaimana cara memanfaat rumah belajar milik pemerintah, bahkan pihak swasta juga telah menyuguhkan kegiatan bimbingan untuk belajar online seperti ruang guru, ada juga yang bernama Zenius, ada yang bernama Klassku, dan ada juga yang bernama Kahoot, dan lainnya.

Akses pelajaran sekolah melalui aplikasi tersebut bermanfaat untuk menggali pengetahuan dan menambah wawasan, sehingga dengan adanya berbagai media tersebut, harusnya sumber daya bidang manusianya sudah berkualitas, sehingga diharapkan media yang tersedia dan dapat diinstal secara gratis bisa dimanfaat atau digunakan dalam kegiatan belajar mengajar. Sangat diperlukan peningkatan kualitas sumber daya manusia (SDM). Keberhasilan pembangunan negara salah satu tolak ukurnya adalah keberhasilan pendidikan. Melalui pendidikan, akan melahirkan generasi penerus yang memiliki kecerdasan intelektual maupun kecerdasan emosional, memiliki keterampilan khusus dan lebih mandiri dalam upaya mencapai pembangunan bangsa Indonesia tercinta.

Namun sering muncul polemik di masyarakat pada metamorfosa saat pandemi Covid 19 melanda negeri. Hal seperti ini tentu dianggap sangat berat oleh pendidik dan siswa/santri. Terutama bagi guru/ustadz, dituntut kreatif dalam penyampaian materi pelajaran dengan online bukan tatap muka langsung. Mengajar online sebenarnya perlu

${ }^{2}$ Marwanto, A. (2021). Pembelajaran pada Anak Sekolah Dasar di Masa Pandemi Covid 19. Jurnal basicedu, 5(4), 2097-2105. 
mempertimbangkan jenjang sekolah (lembaga pendidikan) dan kebutuhannya. Sebab akan menimbulkan tekanan-tekanan secara fisik maupun secara psikis (mental). Dengan pola berpikir yang selalu positif dapat membantu dan mempermudah penggunaan media saat pembelajaran daring berlangsung, sehingga dapat menghasilkan capaian pembelajaran sesuai kompetensi ini yang berkualitas. Pembelajaran siswa dari rumahnya sendiri dengan menggunakan media sebenarnya sangat mengharapkan bantuan dan kerjasama dengan orang tua sebagai role model dalam pendampingan belajar anak agar mengetahui perubahan sikap anak. Jika kita berpikir lebih jauh, sebenarnya adanya covid 19 merupakan sebuah peluang yang sangat baik bagi lembaga pendidikan (sekolah) khususnya dalam adaptasi digital dengan menggunakan teknologi dalam proses pembelajaran.

Setelah covid berlalu, tentu diharapkan lembaga pendidikan sudah terbiasa atau membudaya dalam penggunaan teknologi saat melaksanakan kegiatan belajar mengajar. Ustadz atau dosen bukanlah satu-satunya tonggak penentu dalam adaptasi digital. Ini sebenarnya tantangan yang berat bagi semua guru, para dosen serta orang tua, terlebih tidak sedikit wali siswa yang menyampaikan keluhan terkait media pembelajaran melalui internet ini, apalagi bagi wali siswa yang bekerja dengan istilah work from home. Wali siswa harus tetap mendampingi anak-anaknya, khususnya anaknya yang masih duduk di TK atau PAUD maupun yang masih duduk di pendidikan dasar seperti SD. Ini bukti yang mengingat bahwa belum meratanya diperkenalkan teknologi dalam pemanfaataan media belajar, seperti laptop, gadget, dan lainnya. ${ }^{3}$

Melihat dinamika dari realita yang diuraikan tersebut, Anwaha yang memang sudah adaptif teknologi jauh sebelum dilanda pandemi covid 19, ${ }^{4}$ maka Anwaha tidak mau ikut terjebak dengan masalah tersebut, bagi Anwaha cukup sudah masalah akibat banyaknya siswa pindahan dari sekolah lain yang masuk kelas 2 dan 3 SD namun tidak tahu cara mengeja tulisan, apalagi membaca, tidak mampu menulis dengan kaedah yang benar dan baik dan tidak bisa menyebutkan reretan angka, apalagi berhitung, begitu juga pindahan kelas 6 SD yang belum menguasai pelajaran kelas 4 dan 5, begitu juga halnya

\footnotetext{
${ }^{3}$ Atsani, K.L.G.M.Z. (2020). Transformasi media pembelajaran pada masa Pandemi COVID19. AlHikmah: Jurnal Studi Islam, 1(1), 82-93.

${ }^{4}$ Syahrani, S. (2021). Anwaha's Education Digitalization Mission. Indonesian Journal of Education (INJOE), 1(1), 26-35.
} 
pada jenjang SMP dan SMA sederajat di Anwaha, maka Anwaha punya terobosan tersendiri dengan model kelas Anwaha dan peran wali kelas dalam melaksanakannya, ${ }^{5}$ sehingga santri benar-benar siap mengikuti pembelajaran dan siap menghadapi analisis nasional $^{6}$ dan menghadapi ujian akhir sekolahnya. ${ }^{7}$

Berdasarkan yang peneliti sampaikan pada pendahuluan artikel ini, peneliti tertarik untuk melakukan penelitian lebih dalam mengenai model kelas anwaha dalam rangka manajemen kegiatan belajar mengajar dengan bertatapan langsung bersama santri di masa covid 19.

\section{METODE}

Dalam manajemen pembelajaran tatap muka masa covid menggunakan metode research and development versinya Branch $^{8}$ yang punya ciri khas 5 tahapan yaitulangkah yaitu analisis, desain, pengembangan, implementasi dan evaluasi, tapi peneliti mengadopsinya sampai langkah implementasi saja. Tahapan analisis dilakukan dengan melihat catatan paniti seleksi masuk sekolah di Ponpes Anwaha. Tahap desain dilakukan dengan menyusun rancangan model yang disikusikan dengan asatidz agar rancangan produk bisa dipahami dan lebih mudah untuk diterapkan. Selanjutnya tahap pengembangan adalah penerapan rancangan produk yang disepakati dan tahap implementasi adalah tahap perbaikan model sekaligus penerapannya yang diakhiri dengan tahap evaluasi yakni penuangan catatan-catatan untuk disampaikan kepada pengelola Pondok Pesantren Anwarul Hasaniyyah (Anwaha) Kabupaten Tabalong.

\footnotetext{
${ }^{5}$ Syahrani, S. (2022). Peran Wali Kelas Dalam Pembinaan Disiplin Belajar di Pondok Pesantren Anwarul Hasaniyyah (Anwaha) Kabupaten Tabalong. Al Qalam: Jurnal Ilmiah Keagamaan dan Kemasyarakatan, 16(1), 50-59.

${ }^{6}$ Shaleha, R., \& Shalihah, A. (2021). Analisis Kesiapan Siswa Filial Dambung Raya Dalam Mengikuti Analisis Nasional Berbasis Komputer Di SMAN 1 Bintang Ara Kabupaten Tabalong. Joel: Journal of Educational and Language Research, 1(3), 221-234.

${ }^{7}$ Syahrani, S. (2022). Kesiapan Santri Dalam Mengikuti Analisis Nasional PKPPS Anwarul Hasaniyyah (Anwaha) Kabupaten Tabalong. Adiba: JOURNAL OF EDUCATION, 2(1), 23-31.

${ }^{8}$ Branch, R. M. (2009). Instructional Design The ADDIE Approach. Springer.
} 


\section{HASIL DAN PEMBAHASAN}

Ledakan dampak pandemi terhadap pendidikan ${ }^{9}$ diatasi dengan manajemen pembelajaran tatap muka masa covid 19 bernama model kelas anwaha yang hasil penelitiannya dapat dilihat pada uraian berikut ini:

a. Syarat Penerapan Model Kelas Anwaha

Adapun syarat-syarat dalam penerapan model kelas anwaha sebagai berikut:

1. Terjadinya pandemi atau wabah dalam waktu yang lama

2. Terganggunya pembelajaran yang normal

3. Sebagian besar siswa terbukti tidak menguasai pelajaran pada kelas sebelumnya

4. Tersedianya tenaga pengajar secara kuantitas dan kualitas ${ }^{10}$

5. Kesediaan siswa untuk digabung

6. Kesepakatan dewan guru dan pimpinan sekolah ${ }^{11}$

b. Model Kelas Anwaha

Model kelas Anwaha diluncurkan sebagai gerakan sigap pengelola pendidikan Anwaha yang dimotori oleh Direktur Pendidikan Anwaha atas izin dari Pendiri Pondok Pesantren Anwarul Hasaniyyah (Anwaha) yakni Ustadz Mohammad Ali Bastomi.

Hal ini sebagai tindakan refleksi dari hasil penerimaan santri baru pada semua jenjang sekolah yang diselenggarakan Pondok Pesantren Anwarul Hasaniyyah (Anwaha) yang menunjukkan bahwa santri pindahan sekolah lain yang masuk kelas 2 dan kelas 3 SD ternyata hampir setengah dari jumlah siswanya tidak tahu dan tidak mampu menulis, tidak berani membaca karena tidak tahu huruf dan belum hafal angka hingga tidak tahu cara menghitungnya. Padahal 3 kompetensi tersebut harusnya sudah dimiliki siswa saat mereka naik kelas, tapi kenyataannya demikian, terdapat banyak yang tidak mampu menulis, membaca dan berhitung.

\footnotetext{
${ }^{9}$ Muthmainnah, A., Rahma, D., Robi'ah, F., \& Prihantini, P. (2022). Dampak Pandemi Covid 19 terhadap Kegiatan Ektrskurikuler di Sekolah Dasar. Jurnal Basicedu, 6(1), 394-406.

${ }^{10}$ Renggo, Y. R., \& Rewa, K. A. (2022). Pelatihan dan Penyedian Modul Microsoft Office Secara Online Untuk Peningkatan Kualitas Guru SDK Wolihi di Masa Pandemic Covid 19. Panrita Abdi: Jurnal Pengabdian pada Masyarakat, 6(1), 42-50.

${ }^{11}$ Bay, I. H., \& Pomalato, S. W. D. (2022). Perilaku Kepemimpinan Kepala Sekolah di SMA Negeri 1 Lemito. Berajah Journal, 2(1), 104-110.
} 
Sementara pada santri pindahan yang duduk di kelas 4 ternyata belum menguasai penjumlahan, perkalian dan akar, sedangkan santri pindahan sekolah lain yang duduk di kelas 5 dan kelas 6 belum menguasai pelajaran yang dibahas pada jenjang kelas dibawahnya. Hal yang sama juga dialami santri kelas 7 sampai kelas 12, bukan Cuma pada pelajaran-pelajaran umum seperti matematika, bahasa Inggris dan bahasa Indonesia, tapi juga pelajaran agama seperti fiqih, quran hadits, sejarah Islam dan lainnya.

Melihat kondisi tersebut, pada minggu kedua pembelajaran tahun ajaran 2021/2022 yakni pada tanggal 19 Juli 2021 dilaksanakan kelas gabungan sebagai berikut:

1. Kelas 1, 2 dan 3 bergabung (Jenjang SD)

Gabungan kelas 1, 2, 3 jenjang SD ini diberlakukan karena sekitar 50\% siswa tiap kelas belum bisa menulis, membaca dan berhitung, padahal 3 pelajaran tersebut ada di kelas 1, sehingga diputuskan semua santri kelas 1, kelas 2 dan kelas 3 jenjang sekolah dasar bergabung di kelas 1 .

2. Kelas 4 dan 5 bergabung (Jenjang SD)

Kelas 4 dan 5 SD digabung karena tipologi kedewasaan dan tingkat kesulitan materi hampir sama dan untuk memastikan penguasaan materi kelas 4 , maka siswa kelas 5 harus bergabung dengan siswa kelas 4 .

3. Kelas 6 tersendiri (Jenjang SD)

Siswa kelas 6 tidak bergabung dengan kelas dibawahnya karena ini ada kelas akhir untuk jenjang SD, meski hampir semua siswa kelas ini belum paham pelajaran kelas 4 dan 5, tetap saja kelas ini melakukan pembelajaran terpisah dari kelas dibawahnya, namun semua siswa kelas 6 pada masa penerapan model kelas anwaha, untuk pelajaran yang dibahas adalah pelajaran kelas 4 dan pelajaran kelas 5.

\section{Kelas 7 dan 8 bergabung (Jenjang SMP)}

Siswa kelas 7 dan kelas 8 digabung karena siswa kelas 7 baru masuk dan siswa kelas belum pernah mengikuti pembelajaran tatap muka, meskipun mereka sudah kelas 8, tapi mereka tidak pernah belajar normal selama duduk di kelas 7 , 
sehingga banyak materi yang kurang dikuasai dan banyak siswa yang belum akrab satu sama lain, meski mereka sudah duduk di kelas 8 .

5. Kelas 9 tersendiri (Jenjang SMP)

Siswa kelas 9 tidak bergabung dengan adik kelasnya, namun selama penerapan model kelas anwaha, siswa yang duduk di kelas 9 ini menerima pelajaran yang harusnya dibahas di kelas 7 dan 8 .

6. Kelas 10 dan 11 bergabung (Jenjang SMA)

Rasa canggung dirasakan siswa kelas 11 saat hadir pembelajaran tatap muka masa pandemi, mereka terlihat bingung mana kelasnya, sebab sudah setahun mereka hadir langsung ke sekolah, padahal mereka adalah kakak kelas bagi siswa kelas 10. Tidak cuma sampai disitu, siswa kelas 11 ternyata juga masih lemah bahkan tidak paham pelajaran matematika kelas 10, sehingga dilaksanakanlah kelas gabungan antara kelas 10 dan kelas 11 jenjang SMA ini.

7. Kelas 12 tersendiri (Jenjang SMA)

Siswa kelas 12 tidak bergabung, meskipun kelas sebelumnya yakni kelas 10 dan kelas 11 dilakukan penggabungan kelas, namun selama penerapan model kelas anwaha, guru yang mengajar di kelas 12 akan mengajarkan materi kelas 10 dan materi kelas 11 kepada siswa yang duduk di kelas 12 ini guna memastikan modal awal mengikuti pembelajaran tatap muka kelas akhir jenjang SMA ini.

c. Masa Pelaksanaan Model Kelas Anwaha

Masa berlaku model kelas Anwaha secara umum selama 3 bulan yakni berlangsung selama bulan Juli, Agustus dan September 2021. Secara lebih detail sebenarnya masa berlaku model kelas anwaha untuk tiap santri (siswa) tergantung kemampuan santri, sehingga manajemen kelas yang seperti meski mengejar kualitas, tapi juga kesannya lebih humanis dari sisi manajemennya, ${ }^{12}$ terlebih pondok pesantren sudah terbiasa melaksanakan manajemennya berlandaskan Alquran dan hadits. $^{13}$

Secara garis besar memang ditetapkan pelaksanaannya maksimal 3 bulan, tujuannya agar di bulan ke 4 yakni bulan oktober sudah membahas pelajaran yang

\footnotetext{
${ }^{12}$ Syahrani, S. (2018). Manajemen Kelas yang Humanis. Al-risalah, 14(1), 57-74.

${ }^{13}$ Syahrani, S. (2019). Manajemen Pendidikan dengan Literatur Qur'an. Darul Ulum: Jurnal Ilmiah Keagamaan, Pendidikan dan Kemasyarakatan, 191-203.
} 
harusnya mereka pelajari di kelas itu, yakni pada bulan oktober 2021 siswa kelas 1 sudah mempelajari pelajaran kelas 1, siswa kelas 2 sudah mempelajari materi pelajaran kelas 2, begitu seterusnya sampai kelas 12 .

Pembelajaran normal yang dilaksanakan mulai bulan oktober dimaksudkan agar siswa tetap punya waktu yang cukup untuk menyiapkan dirinya menghadapi ujian semester di kelas yang seharusnya, sedangkan 3 bulan yang lalu tujuannya untuk membekali siswa yang kurang menguasai materi yang harusnya sudah mereka kuasai, sementara bagi siswa yang sudah menguasai pelajaran kelas sebelumnya tujuan tetap ikut kelas gabungan adalah untuk memastikan kematangan siswa dalam menguasai pelajaran pada kelas sebelumnya serta membantu siswa lain dalam pembelajaran model teman sebaya, sebab bagaimanapun bagusnya penjelasan guru, kadang penjelasan dari teman sebaya tetap lebih mudah dipahami siswa.

\section{SIMPULAN}

Model kelas anwaha adalah penggabungan kelas 1, 2 dan 3, gabungan kelas 4 dan 5, kelas 6 tidak digabung, namun selama 3 bulan membahas materi kelas 4 dan 5, selanjutnya penggabungan kelas 7 dan 8 , sedangkan kelas 9 tidak digabung, namun diisi dengan pembahasan materi kelas 7 dan 8 bagi siswa kelas 9, penggabungan kelas 10 dan 11, pembahasan materi kelas 10 dan 11 bagi kelas 12 yang berlangsung selama 3 bulan yakni bulan juli, agustus dan september dan kembali ke kelas normal pada bulan oktober guna persiapan ujian semester ganjil dan dalam manajemen pembelajaran tatap muka dengan model kelas anwaha minimal harus terpenuhi 5 dari 6 syarat dan tidak boleh melakukan kelas gabungan untuk jenjang akhir pendidikan serta penerapan model kelas anwaha maksimal 3 bulan.

\section{DAFTAR PUSTAKA}

Atsani (2020). Transformasi media pembelajaran pada masa Pandemi Covid-19. AlHikmah: Jurnal Studi Islam, 1(1), 82-93.

Bay, I.H., \& Pomalato, S. W. D. (2022). Perilaku Kepemimpinan Kepala sekolah di SMA Negeri 1 Lemito. Berajah Journal, 2(1), 104-110.

Marwanto, A. (2021). Pembelajaran pada Anak Sekolah Dasar di Masa Pandemi Covid 19. Jurnal basicedu, 5(4), 2097-2105. 
Muthmainnah, A., Rahma, D., Robi'ah, F., \& Prihantini, P. (2022). Dampak Pandemi Covid-19 terhadap Kegiatan Ektrskurikuler di Sekolah Dasar. Jurnal Basicedu, 6(1), 394-406.

Rahmatullah, A. S., Mulyasa, E., Syahrani, S., Pongpalilu, F., \& Putri, R. E. (2022). Digital era 4.0: The contribution to education and student psychology. Linguistics and Culture Review, 6, 89-107.

Renggo, Y. R., \& Rewa, K. A. (2022). Pelatihan dan Penyedian Modul Microsoft Office Secara Online Untuk Peningkatan kualitas Guru Sdk wolihi di masa pandemic covid 19. Panrita Abdi Jurnal Pengabdian pada Masyarakat, 6(1), 42-50.

Shaleha, R., \& Shalihah, A. (2021). Analisis Kesiapan Siswa Filial Dambung Raya Dalam Mengikuti Analisis Nasional Berbasis Komputer di SMAN 1 Bintang Ara Kabupaten Tabalong. Joel: Journal of Educational and Language Research, 1(3), 221-234.

Syahrani, S. (2018). Manajemen Kelas yang Humanis. Al-risalah, 14(1), $57-74$.

Syahrani, S. (2019). Manajemen Pendidikan dengan Literatur Qur'an. Darul Ulum: Jurnal Ilmiah Keagamaan, Pendidikan dan Kemasyarakatan, 191-203.

Syahrani, S. (2021). Anwaha's Education Digitalization Mission. Indonesian Journal of Education (INJOE), 1(1), 26-35.

Syahrani, S. (2022). Kesiapan Santri Dalam Mengikuti Analisis Nasional PKPPS Anwarul Hasaniyyah (Anwaha) Kabupaten Tabalong. Adiba: Journal of Education, 2(1), 23-31.

Syahrani, S. (2022). Peran Wali Kelas Dalam Pembinaan Disiplin Belajar di Pondok Pesantren Anwarul Hasaniyyah (Anwaha) Kabupaten Tabalong. Al Qalam: Jurnal Ilmiah Keagamaan dan Kemasyarakatan, 16(1), 50-59. 